\title{
Evaluation of Different Cultivars of Tuberose (Polianthes tuberosa L.) under Humid agro Climatic conditions of Goa
}

\author{
Safeena S.A. ${ }^{1 *}$, Thangam M. ${ }^{2}$ and Singh N.P. ${ }^{3}$ \\ ${ }^{1}$ ICAR-Directorate of Floricultural Research, Pune \\ ${ }^{2}$ ICAR - Central Coastal Agricultural Research Institute, Goa \\ ${ }^{3}$ ICAR-National Institute of Abiotic Stress Management, Baramati \\ Corresponding author: *safeena.sa@icar.gov.in, safeenasandeep@gmail.com
}

\begin{abstract}
Tuberose (Polianthes tuberosa $\mathrm{L}$.) is one of the most important tropical bulbous-ornamental cultivated for production of long-lasting flowers spikes. Adaptation and acclimatization of different cultivars under humid agro-climatic conditions of Goa are to be confirmed for their better performance. The present investigation was conducted to evaluate the performance of tuberose cultivars under agro-climatic conditions of Goa during 20142017. Five single and six double cultivars of tuberose were evaluated during the study period. All the cultivars differed in their growth and flowering behaviour. Among the single cultivars, evaluated, maximum number of florets per spike (47.00) was observed in Pune local whereas spike-length $(75.59 \mathrm{~cm})$ was maximum in Mexican Single. Among the double cultivars, evaluated, maximum plant height $(52.21 \mathrm{~cm}$ ) and maximum number of leaves per plant (59.63) were recorded with cultivar Arka Suvasini. Leaf length was significantly higher $(52.93 \mathrm{~cm})$ in Pearl double whereas leaf width $(2.04 \mathrm{~cm})$ was maximum in Calcutta Double. Days to appearance of flower spike were earlier in Arka Suvasini. Minimum days taken for opening of basal floret (84.88 days) were recorded with cultivar Arka Suvasini. Spike girth $(0.68 \mathrm{~cm})$, Spike fresh-weight $(69.06 \mathrm{~cm})$, floret stalk-length $(3.6 \mathrm{~cm})$, floret diameter $(5.24 \mathrm{~cm})$, weight of individual floret $(3.49 \mathrm{~g})$ and vase life $(7.93$ days) was significantly maximum in Cv. Arka Suvasini followed by Pearl Double. Based on the performance evaluation cv. Mexican Single among single types and cv. Arka Suvasini and Pearl Double among double types could be recommended for commercial cultivation under agro climatic conditions of Goa.
\end{abstract}

Key words: Cultivars, double, Evaluation, Single and Tuberose

\section{INTRODUCTION}

Tuberose (Polianthes tuberosa L.), popularly known as Rajanigandha or Nishigandha is one of the most important tropical ornamental bulbous flowering plants cultivated for production of its long-lasting flower spikes. It is a native of Mexico and belongs to the familyAsparagaceae. Flowers of the Single type (single row of perianth) are commonly used for extraction of essential oil, loose flowers, making garland etc., while that of Double varieties (more than two rows of perianth) are used as cut flowers and for garden display. Flowers of the 'Single' cultivars are more fragrant than 'Double' type and contain 0.08 to 0.14 percent concrete, which is used in high-grade perfumes (Singh and Uma, 1995). In India, tuberose is cultivated commercially in Bagnan, Kolaghat, Midnapur, Panskura, Ranaghat, Krishnanagar of West Bengal; Coimbatore, Dindigul, Kadalur, Krishnagiri, Dharmpurui, Sathyamangalam, Theni and Madurai districts of Tamil Nadu; Pune, Nashik, Ahmednagar, Thane, Sangli of Maharashtra; East Godavari, Guntur, Chittoor, Krishna District of Andhra Pradesh; Mysore, Tumkur, Kolar, Belgaum and Devanhalli taluk in Karnataka ; Guwahati and Jorhat in Assam ; Udaipur, Ajmer and Jaipur in Rajasthan; Navsari and Valsad of Gujarat and parts of Uttar Pradesh and Punjab. Some of the tuberose cultivars have beenintroduced, while some are evolved in India. The information available on recommendations of the suitabletuberose cultivars for growth, floral and 
economicparameters under coastal humid agro climatic conditions of Goa is scanty. Adaptation and acclimatization of different tuberose cultivars under humid agro climatic conditions of Goa are to be confirmed for their better performance. This will enable the farmers to grow released and new introduced and improved cultivars of tuberose and helps in making them understand their superiority over local cultivars. Keeping these facts in view, the present study was conducted to evaluate the performance of different tuberose cultivars under coastal humid climatic conditions of Goa and to find out the suitable tuberose cultivar under agroclimatic conditions of Goa.

\section{MATERIALS AND METHODS}

The present experiment was conducted at Floriculture Research Farm, Horticulture Science Section, ICARCentral Coastal Agricultural Research Institute, Ela, Old Goa, Goa, India during 2014-2017. The state of Goa is located between 140 16" North latitude and $73075^{\prime \prime}$ East longitude with the states of Maharashtra on the North and Karnataka on the East and South and Arabian Sea on the West. The five single type cultivars, viz., Mexican Single, Calcutta Single, Hyderabad Single, Pune Local Single and Phule Rajni,and six double type cultivars (Pearl Double, Arka Suvasini, Bidhan Rajani, Calcutta Double, Hyderabad double and Pune local double) were used for the present study. The uniform sized bulbs of size $(2 \mathrm{~cm}$ diameter) were planted with the spacing of $45 \times 30$ $\mathrm{cm}$ in a plot size of $1.50 \mathrm{~m} \times 1.0 \mathrm{~m}$. Uniform cultural practices were adopted for all the cultivars. The experiment was laid out in randomized block design (RBD) with five replications. Ten plants from each plot were randomly selected for recording various observations. The observations were recorded for two consecutive years on vegetative growth, floral and bulb parameters. The observations, viz., plant height at shoot emergence $(\mathrm{cm})$, number of leaves per plant, leaf length $(\mathrm{cm})$, leaf width $(\mathrm{cm})$, days to appearance of flower spike, number of florets per spike, length of spike $(\mathrm{cm})$, diameter of spike $(\mathrm{cm})$, fresh weight of the spike $(\mathrm{g})$, stalk length of the floret $(\mathrm{cm})$, diameter of the floret $(\mathrm{cm})$, fresh weight of the individual floret (g), vase life of the spikes (days), weight of the bulbs, average number of bulbs per clump and bulblets per clump were recorded. The data recorded on various parameters were compiled and analysed statistically as per the methods described by Panse and Sukhatme (1985).

\section{RESULTS AND DISCUSSION}

Significant differences were observed for various morphological characters and floral quality traits among different single cultivars of tuberose evaluated (Table 1 and 2) under coastal humid agro climatic conditions of Goa.Tallest plant $(49.18 \mathrm{~cm})$, and more number of leaves per plant (82.66) were obtained in cv. Mexican Single in single flower types (Table 1). The highly significant variation in plant height and number of leaves per plant among various tuberose cultivars may be attributable to the hereditary traits, which is further altered by prevailing environmental conditions. The results of the present study are in conformity with the findings of Bhaskar and Reddy

Table 1: Plant growth and floral characteristics in single-type tuberose cultivars under humid agro-climatic conditions of Goa

\begin{tabular}{|l|c|c|c|c|c|c|c|}
\hline Treatments & $\begin{array}{c}\text { Plant height } \\
\text { at shoot } \\
\text { emergence } \\
\text { (cm) }\end{array}$ & $\begin{array}{c}\text { No. of } \\
\text { leaves }\end{array}$ & $\begin{array}{c}\text { Days to } \\
\text { appearance of } \\
\text { initial spike }\end{array}$ & $\begin{array}{c}\text { No. of } \\
\text { spikes/ } \\
\text { clump }\end{array}$ & $\begin{array}{c}\text { No. of } \\
\text { florets/ } \\
\text { spike }\end{array}$ & $\begin{array}{c}\text { Length of } \\
\text { spike } \\
\text { (cm) }\end{array}$ & $\begin{array}{c}\text { Diameter } \\
\text { of spike } \\
\text { (cm) }\end{array}$ \\
\hline Mexican Single & 49.186 & 82.660 & 112.003 & 3.67 & 37.083 & 75.590 & 0.532 \\
\hline Calcutta Single & 46.643 & 64.047 & 114.177 & 3.17 & 35.223 & 68.177 & 0.810 \\
\hline Hyderabad Single & 42.640 & 60.940 & 136.273 & 3.50 & 45.057 & 61.023 & 0.905 \\
\hline Pune Local Single & 38.030 & 63.167 & 123.41 & 2.83 & 37.167 & 62.093 & 0.915 \\
\hline Phule Rajni & 40.387 & 68.170 & 131.073 & 3.13 & 38.050 & 58.113 & 0.540 \\
\hline S.Em+ & 0.115 & 0.858 & 0.564 & 0.093 & 0.704 & 0.294 & 0.005 \\
\hline CD $(0.05)$ & 0.346 & 2.575 & 1.693 & 0.289 & 2.113 & 0.882 & 0.014 \\
\hline
\end{tabular}


(2006), Bhaskaret al. (2006) and Mahawer et al. (2008) in tuberose.

In case of single flower type cultivars earliest flowering was recorded in cv. Mexican Single (112 days) whereas it was very late in Hyderabad single (136.273days) (Table 1) (Fig. 1). The variation in days to appearance of flower spike was chiefly due to the different genetic make-up of the cultivars evaluated under the present study and prevailing environmental conditions. Mexican single recorded significantly maximum spike length $(75.59 \mathrm{~cm})$ (Table 1$)$. This variation in spike length among various tuberose cultivars evaluated in the present study may be due to different genetic make-up of the cultivars and prevailing environmental conditions.

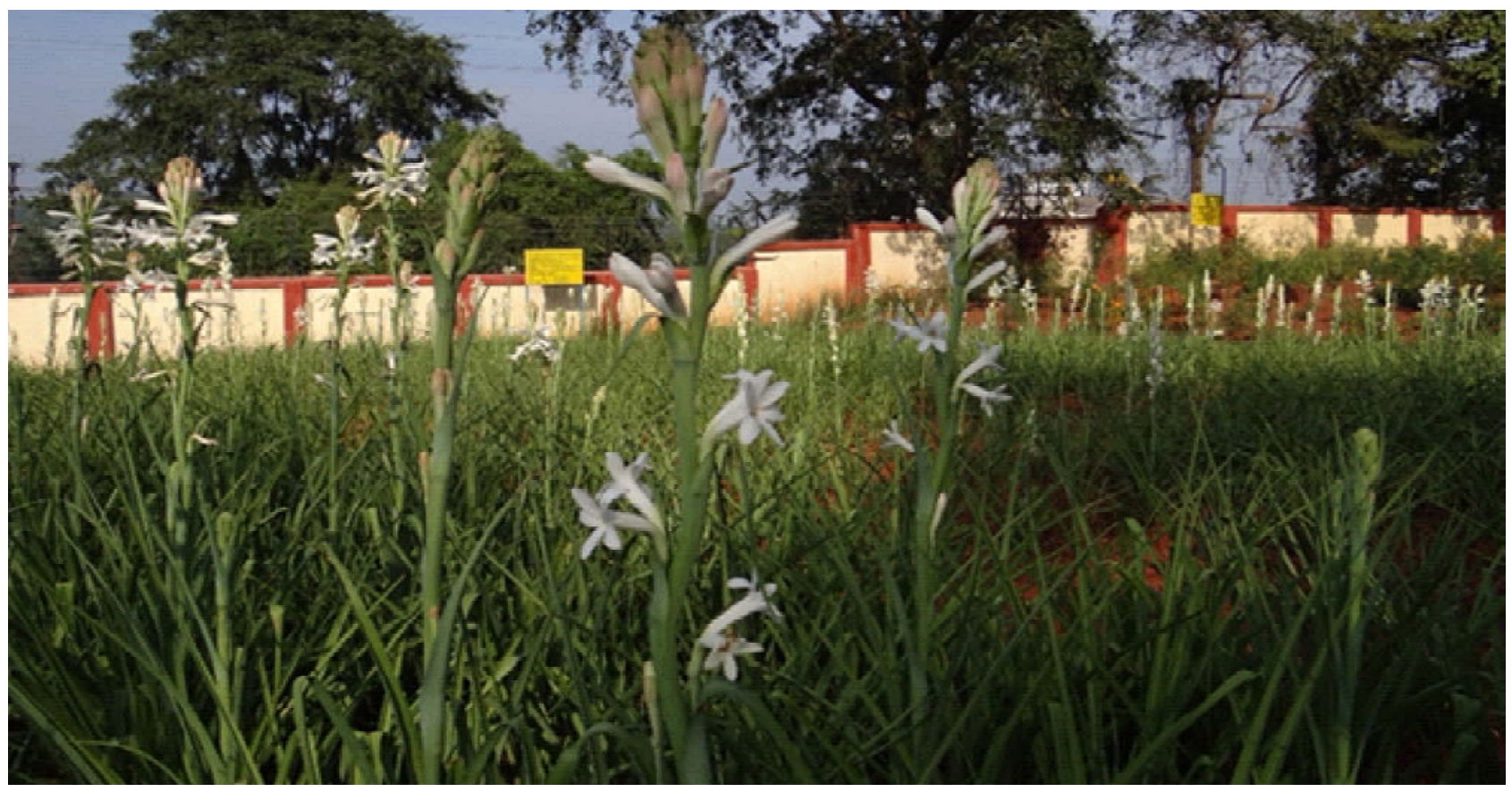

Fig. 1: Tuberose crop in flowering stage under humid agro-climatic conditions of Goa

Significant variation was noticed with respect to number of florets per spike in single types (Table 1). The variation in number of florets per spike may be due to genetic variability among the different cultivars of tuberose and prevailing environmental condition during field trial.Further, in single flower type tuberose cultivars, higher trends for floret stalk length $(1.84 \mathrm{~cm})$, diameter of floret $(4.085 \mathrm{~cm})$ and weight of individual floret $(2.123 \mathrm{~g}$ ) was recorded in cv. Mexican single (Table 2). The variations observed in various floral

Table 2: Floral and Bulb characteristics in single-type tuberose cultivars under humid agro-climatic conditions of Goa

\begin{tabular}{|l|c|c|c|c|c|c|c|}
\hline Treatments & $\begin{array}{c}\text { Floret stalk } \\
\text { length } \\
\text { (cm) }\end{array}$ & $\begin{array}{c}\text { Diameter } \\
\text { of floret } \\
\text { (cm) }\end{array}$ & $\begin{array}{c}\text { Weight of } \\
\text { individual } \\
\text { floret (g) }\end{array}$ & $\begin{array}{c}\text { Vase life } \\
\text { (days) }\end{array}$ & $\begin{array}{c}\text { Weight of } \\
\text { bulb } \\
\text { (g) }\end{array}$ & $\begin{array}{c}\text { No. of } \\
\text { bulbs/ } \\
\text { clump }\end{array}$ & $\begin{array}{c}\text { No. of } \\
\text { bulblets/ } \\
\text { clump }\end{array}$ \\
\hline Mexican Single & 1.840 & 4.085 & 2.123 & 6.702 & 31.953 & 7.467 & 26.000 \\
\hline Calcutta Single & 1.721 & 3.820 & 1.543 & 6.730 & 22.087 & 6.123 & 23.667 \\
\hline Hyderabad Single & 1.372 & 4.047 & 1.717 & 6.920 & 19.700 & 5.680 & 22.633 \\
\hline Pune Local Single & 1.821 & 3.803 & 1.023 & 5.917 & 21.517 & 6.133 & 20.300 \\
\hline Phule Rajni & 1.741 & 3.123 & 1.440 & 5.400 & 19.003 & 5.000 & 20.367 \\
\hline S.Em+ & 0.007 & 0.053 & 0.029 & 0.019 & 0.407 & 0.104 & 0.525 \\
\hline CD $(0.05)$ & 0.020 & 0.160 & 0.087 & 0.059 & 1.221 & 0.313 & 1.575 \\
\hline
\end{tabular}


characters might be due to the presence of sufficient genetic variability as reported earlier by Bichoo et al. (2003) in gladiolus.

Among the single flowered types, Mexican single, Calcutta Single and Hyderabad Single had better vase life of 6.70 days, 6.73 days and 6.92 days respectively (Table 2). Sateesha et al. (2011) reported good vaselife in tuberose cultivars, Vaibhav and Prajwal. The highly significant variation for the vase-life of cut spike among tuberose cultivars may be due to its different genetic make-up with prevailing environmental conditions, which ultimately affects various physiological processes like turgidity of the cell, water uptake through xylem tissue, water loss through transpiration, respiration and breakdown of their served food, which influences vase-life under laboratory conditions.
In case of single flower type cultivar, highest bulb weight per clump was recorded in cultivar Mexican Single (31.953 g), while, lowest (19.003 g) in Phule Rajni (Table 2). These differences might be due to the genetic characters of the different tuberose varieties taken up for the present study.The variation in weight of bulbs per plant among different tuberose cultivars at bulb harvesting stage can be attributed to the distinguished varietal genetic make-up of the cultivar.

Significant differences were observed for various morphological characters and floral quality traits among different doublecultivars of tuberose evaluated (Table 3 - Table 4) under coastal humid agro climatic conditions of Goa.It is evident from the data in Table 3 that out of the different double type tuberose cultivars evaluated for their vegetative characteristics,

Table 3: Plant growth and floral characteristics in double-type tuberose cultivars under humid agro-climatic conditions of Goa

\begin{tabular}{|l|c|c|c|c|c|c|c|c|}
\hline Treatments & $\begin{array}{c}\text { Plant height } \\
\text { at shoot } \\
\text { emergence } \\
\text { (cm) }\end{array}$ & $\begin{array}{c}\text { No.of } \\
\text { leaves } \\
\text { per plant }\end{array}$ & $\begin{array}{c}\text { Leaf } \\
\text { length } \\
\text { (cm) }\end{array}$ & $\begin{array}{c}\text { Leaf } \\
\text { width } \\
\text { (cm) }\end{array}$ & $\begin{array}{c}\text { Days to } \\
\text { appearance } \\
\text { of } \\
\text { flower spike }\end{array}$ & $\begin{array}{c}\text { No. of } \\
\text { spikes/ } / \\
\text { clump }\end{array}$ & $\begin{array}{c}\text { No. of } \\
\text { florets/ } \\
\text { spike }\end{array}$ & $\begin{array}{c}\text { Length } \\
\text { of } \\
\text { spike }\end{array}$ \\
\hline Pearl Double & 42.171 & 44.633 & 52.930 & 1.664 & 164.417 & 3.36 & 43.253 & 71.018 \\
\hline Arka Suvasini & 52.211 & 59.630 & 41.449 & 1.148 & 105.767 & 3.97 & 42.247 & 70.463 \\
\hline Bidhan Rajani & 39.554 & 48.300 & 34.767 & 1.643 & 172.33 & 2.28 & 30.083 & 57.483 \\
\hline $\begin{array}{l}\text { Calcutta } \\
\text { Double }\end{array}$ & 37.300 & 47.500 & 37.257 & 2.040 & 111.433 & 2.39 & 33.233 & 57.507 \\
\hline Pune local & 37.377 & 38.127 & 37.635 & 1.456 & 114.603 & 2.40 & 47.033 & 65.733 \\
\hline $\begin{array}{l}\text { Hyderabad } \\
\text { double }\end{array}$ & 41.030 & 49.927 & 38.307 & 1.138 & 138.06 & 3.17 & 35.540 & 69.063 \\
\hline S. Em+ & 0.214 & 0.148 & 0.132 & 0.086 & 1.896 & 0.028 & 0.292 & 0.240 \\
\hline CD $(0.05)$ & 0.643 & 0.444 & 0.392 & 0.258 & 5.689 & 0.088 & 0.875 & 0.720 \\
\hline
\end{tabular}

the maximum plant height and number of leaves per plant were recorded in cv. Arka Suvasini $(52.21 \mathrm{~cm}$ and 59.63 no's). Panse (1957) reported that the variation in plant height and number of leaves per plant among the cultivars might be due to the genetic constitution of the germplasm, which has close bearing in response to selection.

Out of the six tuberose cultivars evaluated for their floral parameters (Table 3) among the double flower types, days to appearance of flower spike were earlier in Arka Suvasini (105 days) while it was late in Bidhan Rajani(172 days).Similar results with respect to variation in days to first flowering among different cultivars were reported earlier by Bhaskar et al. (2006) and Mahawer et al. (2008). Among the double flowered types, length of the spike $(71 \mathrm{~cm})$ was maximum in Pearl Double as recorded in Table 3. Being genetically controlled factor, significant variation occurred in length of the spike due to the hereditary traits of different cultivars under prevailing 
Evaluation of Different Cultivars of Tuberose (Polianthes tuberosa L.)

Table 4: Floral and bulb characteristics in double-type tuberose cultivars
under humid agro-climatic conditions of Goa

\begin{tabular}{|l|c|c|c|c|c|c|c|c|c|}
\hline Treatments & $\begin{array}{c}\text { Diameter } \\
\text { of spike } \\
\text { (cm) }\end{array}$ & $\begin{array}{c}\text { Fresh } \\
\text { weight } \\
\text { of spike } \\
\text { (g) }\end{array}$ & $\begin{array}{c}\text { Floret } \\
\text { stalk } \\
\text { length } \\
\text { (cm) }\end{array}$ & $\begin{array}{c}\text { Diameter } \\
\text { of floret } \\
\text { (cm) }\end{array}$ & $\begin{array}{c}\text { Weight } \\
\text { of indi. } \\
\text { floret (g) }\end{array}$ & $\begin{array}{c}\text { Vase life } \\
\text { (days) }\end{array}$ & $\begin{array}{c}\text { Weight } \\
\text { of bulb } \\
\text { (g) }\end{array}$ & $\begin{array}{c}\text { No. of } \\
\text { bulbs/ } \\
\text { clump }\end{array}$ & $\begin{array}{c}\text { No. of } \\
\text { bulblets/ } \\
\text { clump }\end{array}$ \\
\hline Pearl Double & 0.645 & 62.504 & 3.523 & 5.186 & 3.383 & 7.600 & 56.067 & 12.733 & 30.167 \\
\hline Arka Suvasini & 0.680 & 69.060 & 3.600 & 5.240 & 3.490 & 7.930 & 52.133 & 11.500 & 29.600 \\
\hline Bidhan Rajani & 0.617 & 25.897 & 1.814 & 4.397 & 1.580 & 5.350 & 34.567 & 9.400 & 26.300 \\
\hline Calcutta Double & 0.547 & 25.217 & 2.007 & 5.000 & 1.750 & 7.023 & 33.467 & 9.733 & 28.167 \\
\hline Pune local & 0.563 & 25.548 & 3.349 & 4.726 & 1.698 & 5.725 & 36.267 & 8.200 & 19.733 \\
\hline Hyderabad Double & 0.542 & 45.311 & 3.021 & 4.068 & 1.481 & 6.030 & 32.800 & 9.167 & 17.800 \\
\hline S. Em+ & 0.017 & 0.180 & 0.042 & 0.032 & 0.013 & 0.056 & 0.236 & 0.034 & 0.087 \\
\hline CD $(0.05)$ & 0.051 & 0.540 & 0.125 & 0.095 & 0.038 & 0.167 & 0.709 & 0.103 & 0.261 \\
\hline
\end{tabular}

environment. Present results are in accordance with the findings of Patil et al. (2009) and Mahawer et al. (2008) who obtained significant variation among the tuberose cultivars for length of the spike.

The two-year pooled data revealed that maximum trend for number of florets per spike (47) was observed in Pune local while minimum trend was recorded in Bidhan Rajani (30) among the double flowered types (Table 3 ). These results are in accordance with the findings of Patil et al. (2009) and Mahawer et al. (2008) who noted significant variation in number of florets per spike in different cultivars of tuberose.The cultivar Arka Suvasini performed better in different floral qualitative traits like spike girth $(0.68$ $\mathrm{cm})$, stalk length of the floret $(3.6 \mathrm{~cm})$, diameter of the floret $(5.24 \mathrm{~cm})$ and weight of individual floret $(3.49 \mathrm{~g})$ which was followed by Pearl Double (Table 4).

Further, the highest fresh weight of the spike was recorded in cultivar Arka Suvasini (69.06 g), followed by the cultivar Pearl Double (62.50 g) among double flower type tuberose cultivars (Table 4). Variation in fresh weight of the spike might be due to different genetic make-up of the different cultivars and prevailing environment conditions. Present findings are in accordance with the findings of Kumar and Yadav (2005) in gladiolus. The vase life was found to be significantly maximum (7.93 days) in cv. Arka Suvasini followed by Pearl Double (7.60 days) among the double flowered tuberose types (Table 4).

The maximum bulb weight per plant were recorded in cultivar Pearl Double (56.06 g), whereas, minimum $(32.80 \mathrm{~g})$ in Hyderabad Double in double flower type of tuberoses evaluated under the present study (Table 4).The cultivars with more number of leaves have higher photosynthetic activity, source sink relationship, thereby accumulating more amount of carbohydrates and improved bulb weight per plant under prevailing environmental conditions. The significant variation in bulb weight of different tuberose cultivars were also recorded earlier by Mahawer et al. 2008.

Based on results obtained, it may be concluded that cv. Mexican Single among single types and cv. Arka Suvasini and Pearl Double among double types could be recommended for commercial cultivation under coastal humid agro climatic conditions of Goa since they were found to be promising in respect of plant growth, floral and bulb characteristics.

\section{ACKNOWLEDGEMENT}

We would like to thank ICAR- Central Coastal Agricultural Research Institute, Ela, Old Goa, Goa, India for providing the necessary facilities to carry out this research work. 


\section{REFERENCES}

Bhaskar, V.V. and Reddy, P.S. 2006. Performance of tuberose (Polianthes tuberosa L.) cultivars under the northern Telengana zone of Andhra Pradesh. In:National Symposium on Ornamental BulbousCrops held on 5-6 December, 2006 at SVBPUAT, Meerut (U.P.).pp. 30.

Bhaskar, J., Sobhana, A. and Rajeevan, P.K. 2006. Performance evaluation of tuberose Polianthes tuberosa (L.) varieties. In: National Symposium on Ornamental Bulbous Crops held on 5-6 December 2006 at SVBPUAT, Meerut (U.P.), pp. 31.

Bichoo, G.A., Jhon and Wani, S.A. 2003. Genetic variabilityin some quantitative characters of gladiolus. J. Orn.Hort., 5: 22-24.

Kumar, R. and Yadav, D.S. 2005. Evaluation of gladiolus cultivars under sub-tropical mid-hills of Meghalaya. Orn. Hort. 8: 86-90.

Mahawer, L.N., Shukla, A.K. and Bairwa, H.L. 2008. Performance of various tuberose (Polianthes tuberosa
L.) cultivars under agroclimatic zone IV-A sub-humid southern plains and aravalli hills of Rajasthan. In: National Symposium on Recent Advances in Floriculture held on 4-6 March, 2008 at NAU, Navsari, Gujarat, pp.73.

Panse, V. G. and Sukhatme, P.V. 1985. Statistical Methods for Agricultural Workers, ICAR, New Delhi, 4th edition.

Patil, V.S., Munikrishnappa, P.M. and Shantappa, T. 2009. Performance of growth and yield of different genotypes of tuberose under transitional tract of north Karnataka. J. Ecobiol.,24: 327-333.

Sateesha, G.R., Kumar, Anil and Biradar, M.S. 2011. Performance of different tuberose varieties under field conditions. Plant Arch.,11: 359-60

Singh, K.P. and Uma, S. 1995. Studies on ratoon crop in tuberose cv. Single and Double. Indian Perfumer, 39(4): 158-160.

(Received on 25.9.2017, Revised and accepted on 12.11.2019) 